\title{
Early sowing can improve irrigation water use efficiency and yield of common bean ${ }^{1}$
}

\author{
Gisele Carneiro da Silva Teixeira ${ }^{2}$, Luís Fernando Stone ${ }^{3}$, \\ Alberto Baêta dos Santos ${ }^{3}$, Silvando Carlos da Silva ${ }^{3}$, Alexandre Bryan Heinemann ${ }^{3}$
}

\begin{abstract}
One of the great challenges in the use of irrigation, from an economic and environmental point of view, is to optimize the amount of water used in the production system. This study aimed at determining the viability of early sowing in the fall/winter harvest season, as well as its effects on the irrigation water use efficiency and yield of common bean. A crop model named CSM-CROPGRO-Dry bean, which simulates growth, development and yield of common bean as a function of environmental conditions, crop management and cultivar-specific parameters, was used to simulate the effects of 12 sowing dates on the irrigation water use efficiency and yield of the Pérola and BRS Radiante common bean cultivars. The simulated dates were as it follows: March 1st, 10 and 20 and April 1st, 10 and 20 (considered early); and May 1st, 10 and 20 and June 1st, 10 and 20 (considered traditional). The early sowing results in greater water economy than the traditional sowing season. Sowing in March provides a higher grain yield for the BRS Radiante cultivar and is similar to the traditional sowing of the Pérola cultivar. Concerning grain yield and irrigation water use efficiency, it is feasible to sow both cultivars in March.
\end{abstract}

KEYWORDS: Phaseolus vulgaris L.; CSM-CROPGRO-Dry bean simulation model; sowing date.

\section{INTRODUCTION}

Common bean (Phaseolus vulgaris L.) is the most cultivated species of the Phaseolus genus. Brazil is the world's largest producer of this species, with an annual average reaching 2.6 million tons, in the $2015 / 2016$ crop season. This estimate considers the sum of the three crop seasons usually cultivated: wet, dry and fall/winter. Sowing in the fall/winter takes place from May to June 20 .

\section{RESUMO}

Antecipação da semeadura pode aumentar a eficiência no uso da água de irrigação e a produtividade de feijoeiro

Um dos grandes desafios na utilização de irrigação, do ponto de vista econômico e ambiental, é otimizar a quantidade de água aplicada ao sistema produtivo. Objetivou-se determinar a viabilidade da antecipação da semeadura na safra outono/inverno, bem como seus efeitos na eficiência do uso da água de irrigação e na produtividade de feijoeiro. Um modelo de cultura denominado CSM-CROPGRO-Dry bean, o qual simula o crescimento, desenvolvimento e produtividade do feijoeiro como função das condições ambientais, manejo da cultura e parâmetros específicos da cultivar, foi usado para simular os efeitos de 12 datas de semeadura na eficiência do uso da água de irrigação e na produtividade das cultivares de feijoeiro Pérola e BRS Radiante. As datas simuladas foram: $1^{\circ}, 10$ e 20 de março e $1^{\circ}$, 10 e 20 de abril (consideradas antecipadas); e $1^{\circ}, 10$ e 20 de maio e $1^{\circ}, 10$ e 20 de junho (consideradas tradicionais). A antecipação da semeadura resulta em maior economia de água, em relação à época de semeadura tradicional. Semeaduras em março propiciam maior produtividade de grãos para a cultivar BRS Radiante e são similares às semeaduras tradicionais para a cultivar Pérola. Considerando-se a produtividade de grãos e a eficiência do uso da água de irrigação, é viável realizar a semeadura de ambas as cultivares em março.

PALAVRAS-CHAVE: Phaseolus vulgaris L.; modelo de simulação CSM-CROPGRO-Dry bean; data de semeadura.

The Brazilian Midwest region is the second largest domestic producer, accounting for $46.7 \%$ of the total production, only surpassed by the Southeast region, with $50.3 \%$. The Goiás State is the largest producer in the Midwest and ranks as the second in the country, accounting for $32.9 \%$ of the total production, only surpassed by the Minas Gerais State, with $39.1 \%$ (IBGE 2016). In Goiás, the fall/winter bean crop is mainly produced in Cristalina, which ranked as the second largest in the 2012 harvest, with $64,800 \mathrm{t}$ and an average yield of $2,400 \mathrm{~kg} \mathrm{ha}^{-1}$

1. Manuscript received in Sep./2016 and accepted for publication in Mar./2017 (http://dx.doi.org/10.1590/1983-40632016v4743193).

2. Universidade Estadual de Goiás, Posse, GO, Brazil.E-mail: gisele.agronomia@hotmail.com.

3. Empresa Brasileira de Pesquisa Agropecuária (Embrapa Arroz e Feijão), Santo Antônio de Goiás, GO, Brazil.

E-mails: luis.stone@embrapa.br, alberto.baeta@embrapa.br, silvando.silva@embrapa.br, alexandre.heinemann@embrapa.br. 
(IBGE 2012). Cristalina holds $25 \%$ of the 2,519 central pivots in the Goiás State and the area served by this irrigation system corresponds to 50,722 ha (Lima et al. 2015).

The fall/winter harvest season is responsible for changing the profile of the common bean crop in Brazil, which was previously considered only as a subsistence crop. Common bean harvested in the fall/winter is generally cultivated by high technological farmers, who use irrigation and nitrogen fertilizers, when compared with the wet season harvest (sowing from November to December) and the dry season harvest (sowing from January to February), in the Goiás State. The fall/winter season is characterized by milder air temperatures and lower air humidity (Heinemann et al. 2016), which result in low biotic and abiotic stresses. In addition, this harvest season contributes to the regularity of common bean stocks throughout the year, thus reducing market price swings. Despite all the success that the fall/winter harvest provides to its productive chain, sustainability is constantly sought, especially in what concerns the economy of irrigation water.

Irrigated agriculture accounts for $40 \%$ of the world's food supply. De Fraiture \& Wichelns (2010) state that the importance of irrigation for food production tends to increase with an increased population and consumption. The authors also point out that urban and industrial development areas demand an increasing share of water resources and, at the same time, that water scarcity is increasing in several important agricultural areas.

Improvement in the water use efficiency by crops is one of the main approaches adopted to overcome the impacts of reducing water availability for agriculture (Boutraa 2010). An alternative for farmers, that is feasible and of easy adoption to increase the irrigation water use efficiency, maintaining high yield rates, is to advance the sowing time to March, for the fall/winter season. Anticipation of sowing is sought to take advantage of the period in which there is still adequate soil moisture provided by rainfall.

So far, early sowing is not performed because of the whitefly [Bemisa tabaci (Genn.)] infestation from soybean crops. However, with the prospect of releasing a cultivar resistant to the golden mosaic virus, which is transmitted by the whitefly (Pinheiro et al. 2014), it is believed that the advance of sowing time may be feasible. Early sowing has resulted in higher yields, as observed by Gomes Junior et al. (2005), in Selvíria, Mato Grosso do Sul State, where common bean sowed in April resulted in a $30.9 \%$ increase in yield, if compared with that of June.

The effects of early sowing on the irrigation water use efficiency and common bean yield can be estimated using simulation models of growth, development and yield. These models use genetic coefficients as input, which allow simulating the performance of genotypes in different environments. Simulation models are used to evaluate management strategies in each specific condition, such as when irrigation management is tested. Irrigation can be simulated to predict effects on crop yield and hydrological components such as evapotranspiration and water requirement (Dallacort et al. 2010).

The use of simulation models is more convenient in determining the most suitable sowing date, since the climatic effect on the development and yield of a crop can be evaluated over a longer number of years and sowing dates. In addition, the biotic effects can be avoided, what would be much more difficult and costly with field experiments.

This study aimed at determining the viability of early sowing in the fall/winter harvest season, as well as its effects on the irrigation water use efficiency and yield of common bean.

\section{MATERIAL AND METHODS}

The study area comprises the municipality of Cristalina, Goiás State, Brazil, with an area of

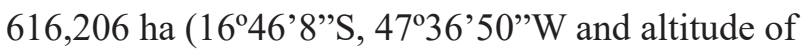
$1,237 \mathrm{~m})$. The predominant climate in the region, according to the Köppen's classification, is rainy tropical, Aw-Savannah, which is characteristic of tropical humid climates (Cardoso et al. 2014), with two well-defined seasons: dry in the winter (June to August) and wet in the summer (November to March). April/May and September/October are the transition months from dry to wet seasons, respectively (Bustamante et al. 2012). The average annual rainfall is $1,422 \mathrm{~mm}$.

Yield, growth and development of common bean were simulated using the CSM-CROPGRO-Dry bean process-oriented model (Jones et al. 2003). This model has been widely applied in Brazil for different purposes, in agricultural research (Heinemann et al. 2000, 2002 and 2016, Lima Filho et al. 2013a and 2013b, Oliveira et al. 2012). The crop model 
requires daily weather data, soil surface and profile information, and detailed crop management (variety, row spacing, plant population, fertilizer and irrigation application dates and amounts) as input. Crop genetic information is defined in a crop species file that is provided by the model and cultivar information that should be provided by the user. The simulations are conducted at a daily step and, at the end of the day, the plant and soil water, nitrogen and carbon balances are updated, as well as the crop vegetative and reproductive development stage. The outputs include agronomic parameters (phenological development, dry matter accumulation, leaf area index, physiological indices and grain yield) and changes in soil water, carbon and nitrogen, that take place under the cropping system over time (Jones et al. 2003).

For the water balance, the soil profile is considered as one-dimensional (only vertical) and the following equation is used to calculate the daily changes in the soil water content:

$$
\Delta \mathrm{S}=\mathrm{P}+\mathrm{I}-\mathrm{E}_{\mathrm{p}}-\mathrm{E}_{\mathrm{s}}-\mathrm{R}-\mathrm{D}
$$

where $\Delta \mathrm{S}$ is the variation in the soil water storage, $\mathrm{P}$ and $\mathrm{I}$ the input data for rainfall and irrigation, $\mathrm{E}_{\mathrm{p}}$ and $\mathrm{E}_{\mathrm{s}}$ the output data for plant transpiration and soil water evaporation, $\mathrm{R}$ stands for runoff and $\mathrm{D}$ for drainage, all terms expressed as $\mathrm{mm}$.

The water in the soil is distributed in several layers (up to 20) and the increase in depth is given by the user (Heinemann et al. 2002). The infiltration of water into the soil is calculated by the difference between rainfall or irrigation and runoff. Runoff is estimated by the curve number technique (USA 1985). Drainage is calculated assuming a fixed saturated soil water capacity, as $\mathrm{m}^{3} \mathrm{~m}^{-3}$, and a fixed drained upper limit, which is equivalent to the soil water storage capacity, as $\mathrm{m}^{3} \mathrm{~m}^{-3}$. The water content in the soil varies among the lower limit, permanent wilt point and saturated soil water capacity. When the water content in a given soil layer is above the soil water storage capacity, the water is drained to the next layer, based on a tipping bucket approach (Heinemann et al. 2002). Evapotranspiration is calculated using the procedure described by Ritchie (1972), in which the soil water evaporation and plant transpiration are calculated separately. Potential evapotranspiration is calculated by the PriestleyTaylor method (Silva et al. 2011).

Daily rainfall, maximum and minimum air temperatures, and global solar radiation were obtained from the climatological station of the National Institute of Meteorology, in Cristalina $\left(17.11^{\circ} \mathrm{S}\right.$, $47.31^{\circ} \mathrm{W}$ and altitude of $1,189 \mathrm{~m}$ ), from 1980 to 2013. The soil physical and water characteristics and the root growth factor required to run the model are described in Table 1. Soil data are average values obtained from samples of Dystrophic Red Latosols, predominant in the region of Cristalina, which were analyzed at the soil laboratory of the Embrapa Arroz e Feijão. Root growth factors were obtained from field experiments in which trenches were opened to evaluate the common bean root profile, and a grid net was placed against the profile wall (Brasil et al. 2007).

The Pérola and BRS Radiante common bean cultivars, with contrasting cycle and growth habit, were selected for the study. Pérola has a semiprostrate architecture, type III indeterminate growth habit and cycle of 90 days, while BRS Radiante has an erect architecture, type I determined growth habit and cycle of 75 days. Both cultivars are grown in the region and used as standard in experiments of the Embrapa Arroz e Feijão breeding program. They also differ in pod filling period and solar radiation use efficiency (Teixeira et al. 2015). The crop genetic information, which characterizes a particular cultivar, used in the model was derived from field experiments and was described in detail by Heinemann et al. (2016). According to Jones et al. (2003), crop genetic information applies to different environments.

Table 1. Physical-water characteristics of the soil and root growth factor used in the simulations.

\begin{tabular}{ccccc}
\hline Depth & Permanent wilt point & Field capacity & Saturated soil water capacity & \multirow{2}{*}{ Root growth factor } \\
\cline { 2 - 4 } $\mathrm{cm}$ & & 0.383 & 0.491 & 1.00 \\
$0-10$ & 0.280 & 0.367 & 0.496 & 0.80 \\
$10-20$ & 0.277 & 0.348 & 0.485 & 0.60 \\
$20-30$ & 0.281 & 0.346 & 0.491 & 0.30 \\
$30-40$ & 0.280 & 0.346 & 0.491 & 0.20 \\
$40-50$ & 0.280 & 0.346 & 0.491 & 0.00 \\
$50-60$ & 0.280 & & & \\
\hline
\end{tabular}


The model was run with data from the climatological series from 1980 to 2013, a total of 33 harvest seasons, two cultivars (Pérola and BRS Radiante), one soil type (Table 1), 12 sowing dates and the agronomic practices adopted in the region (sowing depth of $0.03 \mathrm{~m}$ and row spacing of $0.45 \mathrm{~m}$ ), totaling 792 simulations. The simulated sowing dates were defined every 10 days, from March 1 st to June 20. The sowing period of winter common bean in Cristalina is from May to June 20. After June 20, sowing is not suitable, due to the sanitary void from September 20 to October 20, aiming to reduce the whitefly population, which spreads the bean golden mosaic virus and the cowpea mild mottle virus. Sowing before May brings a high risk of golden mosaic occurrence, because of the whitefly population coming from the soybean crops. As aforementioned, the release of golden mosaic resistant cultivars will allow an early sowing, which can be carried out from March to April in the region.

Linear regression was used to quantify the economy of irrigation water depth provided by the advance of sowing time. Irrigation water use efficiency was calculated with the following equation:

$$
\mathrm{WUE}=\mathrm{Y} / 10 \mathrm{I}
$$

where WUE is the irrigation water use efficiency $\left(\mathrm{kg} \mathrm{m}^{-3}\right), \mathrm{Y}$ the simulated common bean yield $\left(\mathrm{kg} \mathrm{ha}^{-1}\right)$ and I the irrigation depth applied (mm).
The criterion to determine the sowing date that will provide the lowest irrigation water use efficiency was the cumulative distribution function:

$$
\mathrm{F}(\mathrm{x})=\mathrm{P}(\mathrm{X} \leq \mathrm{x}), \mathrm{x} \varepsilon \text { Real }
$$

where $\mathrm{F}(\mathrm{x})$ is the cumulative distribution function $(\%)$ and $\mathrm{P}(\mathrm{X} \leq \mathrm{x})$ the probability of the variable $\mathrm{X}$ (irrigation water use efficiency) being less than or equal to $\mathrm{x}$.

For a better understanding of the effects of climatic variables on simulated yield, the Pearson's correlation analysis was performed considering the dates of early sowing and dates of traditional sowing (current). The analyses were carried out with the R software.

\section{RESULTS AND DISCUSSION}

The simulated yield for the conditions of Cristalina varied with cultivars and sowing dates (Figure 1). Pérola produced higher yields than BRS Radiante in all simulated dates. The mean yields of the 12 sowing dates were $3,200 \mathrm{~kg} \mathrm{ha}^{-1}$ for Pérola and 2,856 $\mathrm{kg} \mathrm{ha}^{-1}$ for BRS Radiante.

The simulated yield for Pérola decreased from the sowing date (March 1st; 3,278 $\mathrm{kg} \mathrm{ha}^{-1}$ ) to May $10\left(3,056 \mathrm{~kg} \mathrm{ha}^{-1}\right)$ and then increased until the last simulated date, reaching 3,283 $\mathrm{kg} \mathrm{ha}^{-1}$. However, the advance of sowing to March and April did not

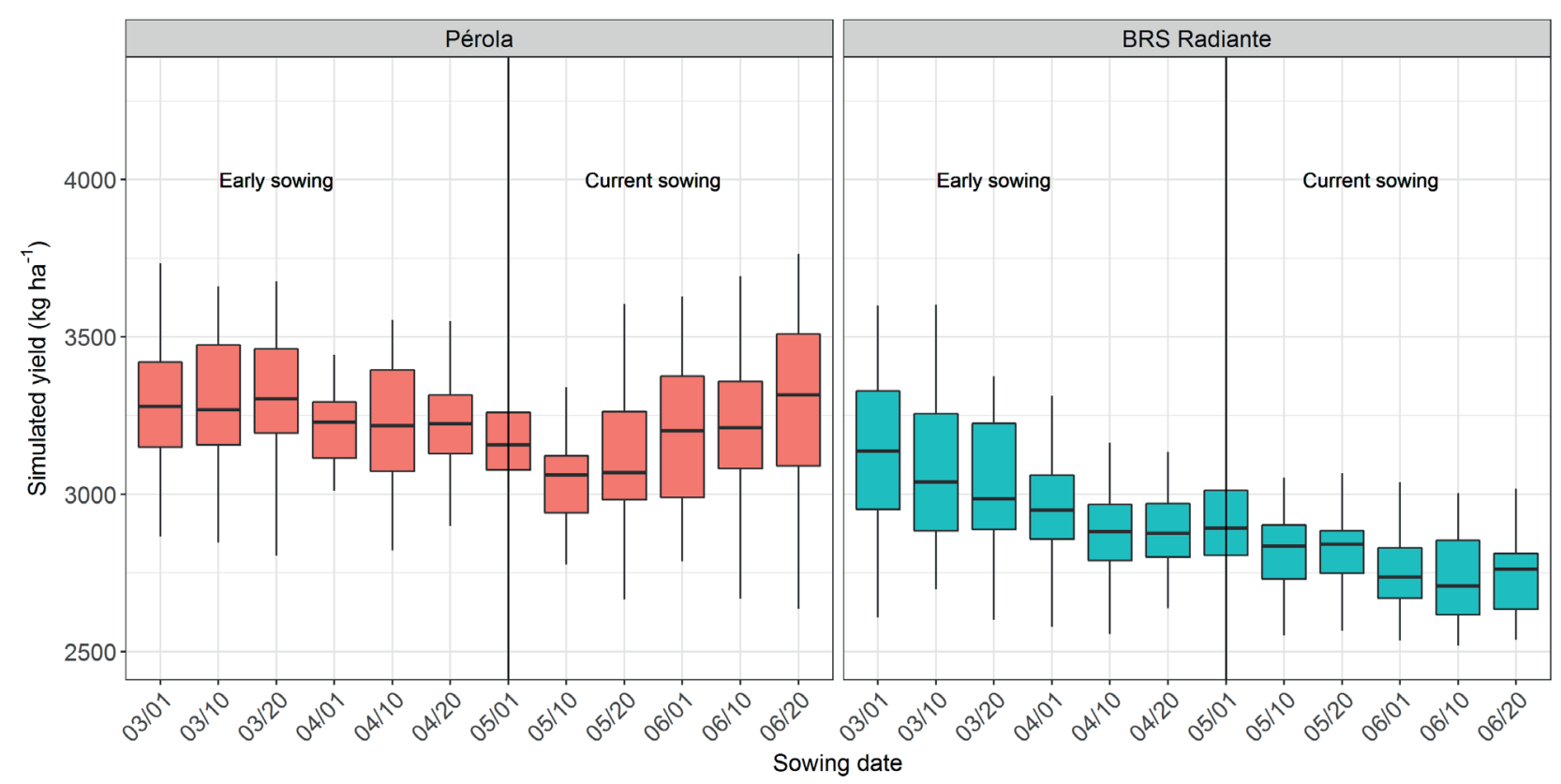

Figure 1. Simulated yield of the Pérola and BRS Radiante common bean cultivars for the sowing dates tested. In the box plot, boxes extend from the 25 th to the 75 th sample percentiles of yield, the thick horizontal line represents the median and whiskers extend to 1.5 times the interquartile range. 
cause a significant reduction in the Pérola yield, with averages of 3,265 kg ha-1 (March) and 3,194 kg ha-1 (April). BRS Radiante showed a yield decrease with the delay in sowing, varying from $3,127 \mathrm{~kg} \mathrm{ha}^{-1}$ in March 1st to 2,628 $\mathrm{kg} \mathrm{ha}^{-1}$ in June 20.

Gomes Junior et al. (2005), in Selvíria, obtained higher common bean yields when sowing was carried out in April than in June. Vieira et al. (1991), in the Minas Gerais State, also observed a decrease in the yield of fall/winter common beans, as sowing advanced beyond April. This results are mainly due to the low air temperatures, which harm the formation and filling of seeds in the pods (Andrade et al. 2015).

Simulated yields for BRS Radiante were above the average recorded for Cristalina, which is $2,400 \mathrm{~kg} \mathrm{ha}^{-1}$ (IBGE 2012), while Pérola had yields exceeding $3,000 \mathrm{~kg} \mathrm{ha}^{-1}$, which is frequently achieved in the fall/winter crop in Goiás and Distrito Federal (IBGE 2016). For both regions, the months of April and May are characterized as being a climatic transition between the hot and rainy period and the cold and dry period of the year (Bustamante et al. 2012). These transitional climatic conditions are responsible for the higher yield in early sowing.
The averages of minimum and maximum air temperatures and solar radiation decreased from March to the end of April and began to increase in June (Figure 2). The variation of average climatic data between the two cultivars is due to differences in the crop cycle. The reduction of air temperature is one of the causes of the decreased simulated yield for both cultivars, when the sowing date is delayed, since the correlations between yield and minimum and maximum air temperatures were positive and significant for both cultivars, in this period (Table 2).

Table 2. Pearson's correlation between climatic variables and simulated yields, considering early sowing (March to April) and current sowing (May to June) $(n=6)$.

\begin{tabular}{|c|c|c|c|}
\hline \multirow{2}{*}{ Yield $\left(\mathrm{kg} \mathrm{ha}^{-1}\right)$} & GSR & MAT & MIT \\
\hline & $\mathrm{MJ} \mathrm{m}^{-2} \mathrm{~d}^{-1}$ & \multicolumn{2}{|c|}{${ }^{\circ} \mathrm{C}$} \\
\hline \multicolumn{4}{|l|}{ Pérola } \\
\hline Early sowing & $0.67^{\mathrm{ns}}$ & $0.80 *$ & $0.80 *$ \\
\hline Current sowing & $0.89 *$ & $0.89 *$ & $0.96 * *$ \\
\hline \multicolumn{4}{|l|}{ BRS Radiante } \\
\hline Early sowing & $0.99 * *$ & $0.98^{* *}$ & $0.98 * *$ \\
\hline Current sowing & $-0.84 *$ & $-0.69^{\mathrm{ns}}$ & $-0.19^{\text {ns }}$ \\
\hline
\end{tabular}

, ** significant at $5 \%$ and $1 \%$, respectively; ${ }^{\text {ns }}$ non-significant. GSR: average global solar radiation per crop cycle; MAT: average maximum air temperature per crop cycle; MIT: average minimum air temperature per crop cycle.
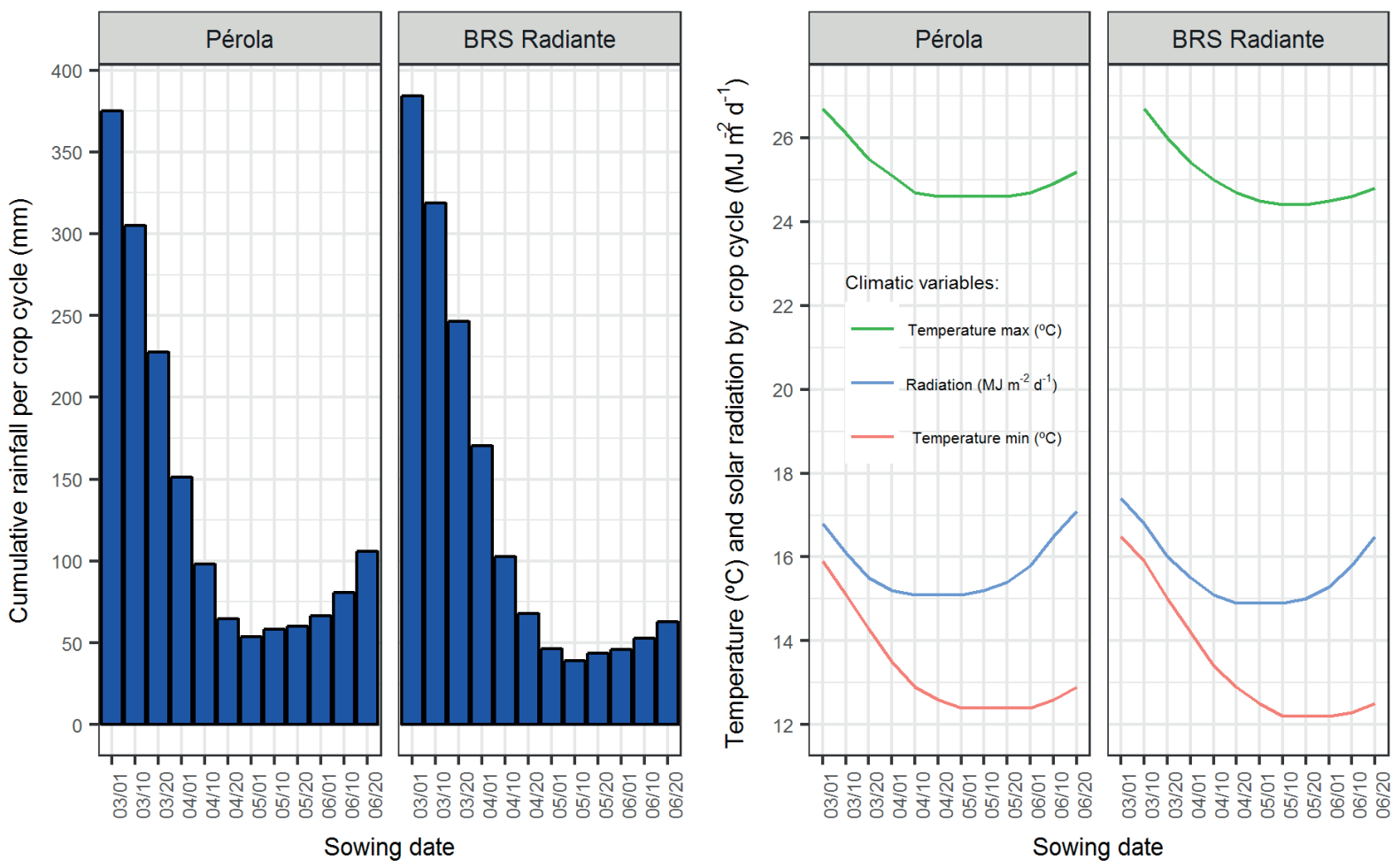

Figure 2. Average cumulative rainfall, maximum and minimum air temperatures and global solar radiation per crop cycle, in Cristalina, Goiás State, Brazil. 
According to Andrade et al. (2015), the range between $15^{\circ} \mathrm{C}$ and $29^{\circ} \mathrm{C}$ is ideal for the development of common bean. For Pérola, the minimum and maximum average air temperatures per crop cycle were $14.8{ }^{\circ} \mathrm{C}$ and $26.1^{\circ} \mathrm{C}$ for sowing in March and $13.1{ }^{\circ} \mathrm{C}$ and $24.9^{\circ} \mathrm{C}$ for sowing in April, respectively. BRS Radiante, with a smaller cycle, had average minimum and maximum air temperatures per crop cycle of $15.5^{\circ} \mathrm{C}$ and $26.6^{\circ} \mathrm{C}$ and $13.5^{\circ} \mathrm{C}$ and $25.1^{\circ} \mathrm{C}$, for the same months.

The BRS Radiante yield was also positively affected by solar radiation (Table 2), which decreased from March (Figure 2). Didonet \& Silva (2004) observed that more pods are produced when the plants receive high solar radiation in the period between emergence and the beginning of flowering.

In the period of the current sowing, the Pérola yield was positively correlated with minimum and maximum air temperatures and with solar radiation. The BRS Radiante yield, in turn, showed a negative correlation with solar radiation. Didonet (2010) found, for the Pérola, BRS Valente and Jalo Precoce cultivars, that the average global radiation incident from emergence to flower bud development showed no significant correlation with yield, but the radiation incident from emergence to the third trifoliolate leaf was negatively correlated with yield. The author states that the higher radiation probably favored a greater retention of pods than the ability of plants to sustain them, explaining the negative effect of solar radiation on common bean yield.

The low air temperatures recorded from March reflected in the cultivar cycle length, which increased with sowing from March 1st to May (Figure 3). Vieira et al. (1991) and Andrade et al. (2015) also found that low air temperatures increased the cycle of medium and early cycle common beans.

The amount of water required in irrigation varied between sowing dates and cultivars (Figure 4). The average amount of water required among the simulated sowing dates was $232 \mathrm{~mm}$ for Pérola and $189 \mathrm{~mm}$ for BRS Radiante. The lower water requirement of BRS Radiante is mainly due to its shorter cycle.

The lowest amounts of water required for both cultivars occurred when simulated sowing occurred in March, with $179 \mathrm{~mm}$ for Pérola and $136 \mathrm{~mm}$ for BRS Radiante. This is because with early sowing there is more rainfall during their cycle (Figure 2), requiring less supplemental irrigation. On the other hand, the highest amounts of water required by both cultivars were recorded in the sowings from May 1st, with average of $258 \mathrm{~mm}$ for Pérola and $216 \mathrm{~mm}$ for BRS Radiante. This is explained by the reduced rainfall in this period, resulting in high demands for irrigation, which practically had to provide the total amount of water needed by the crop.

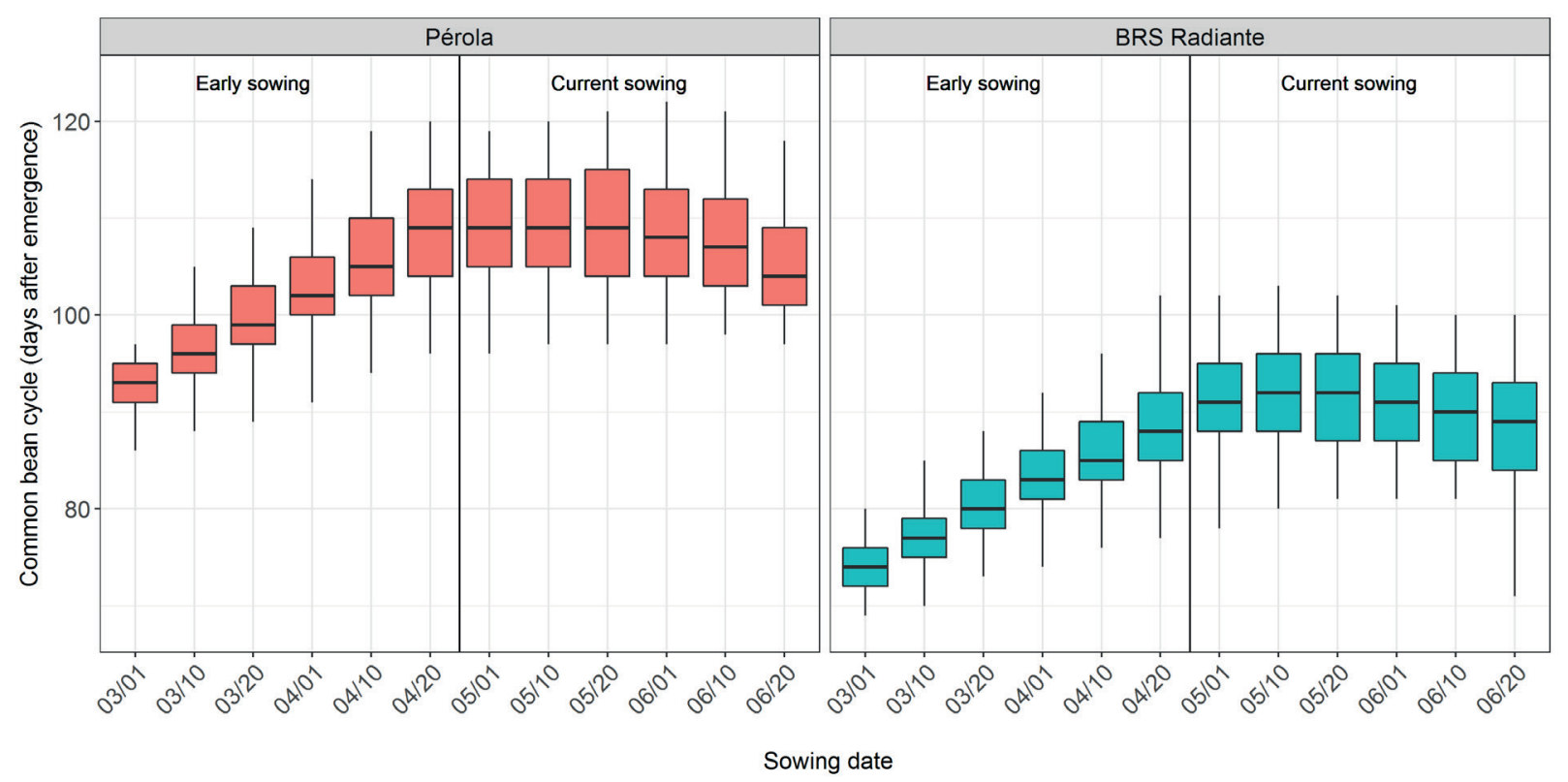

Figure 3. Simulated cycle length of the Pérola and BRS Radiante common bean cultivars for the sowing dates tested. In the box plot, boxes extend from the 25 th to the 75 th sample percentiles of yield, the thick horizontal line represents the median and whiskers extend to 1.5 times the interquartile range. 
The largest irrigation depths required were lower than that reported by Mantovani et al. (2012) of $418 \mathrm{~mm}$, during the cycle of irrigated Carioca common bean cultivar, in Cristalina, with yield of $2,947 \mathrm{~kg} \mathrm{ha}^{-1}$. Our results, on the other hand, are close to that reported by Matzenauer et al. (1999), in which the water requirement of 90-day-cycle bean cultivars is approximately $300 \mathrm{~mm}$. However, Arf et al. (2004), in Selvíria, observed that the yield of the IAC Carioca Eté cultivar did not change with irrigation depths ranging 150-287 mm.

Early sowing between March and early April provided significant economy of irrigation water, both because of rainfall exploitation and the shorter cycle of cultivars. For Pérola, each day of earlier sowing from May 1st provided an economy of $1.70 \mathrm{~mm}$, while for BRS Radiante it was $1.52 \mathrm{~mm}$ (Figure 5).

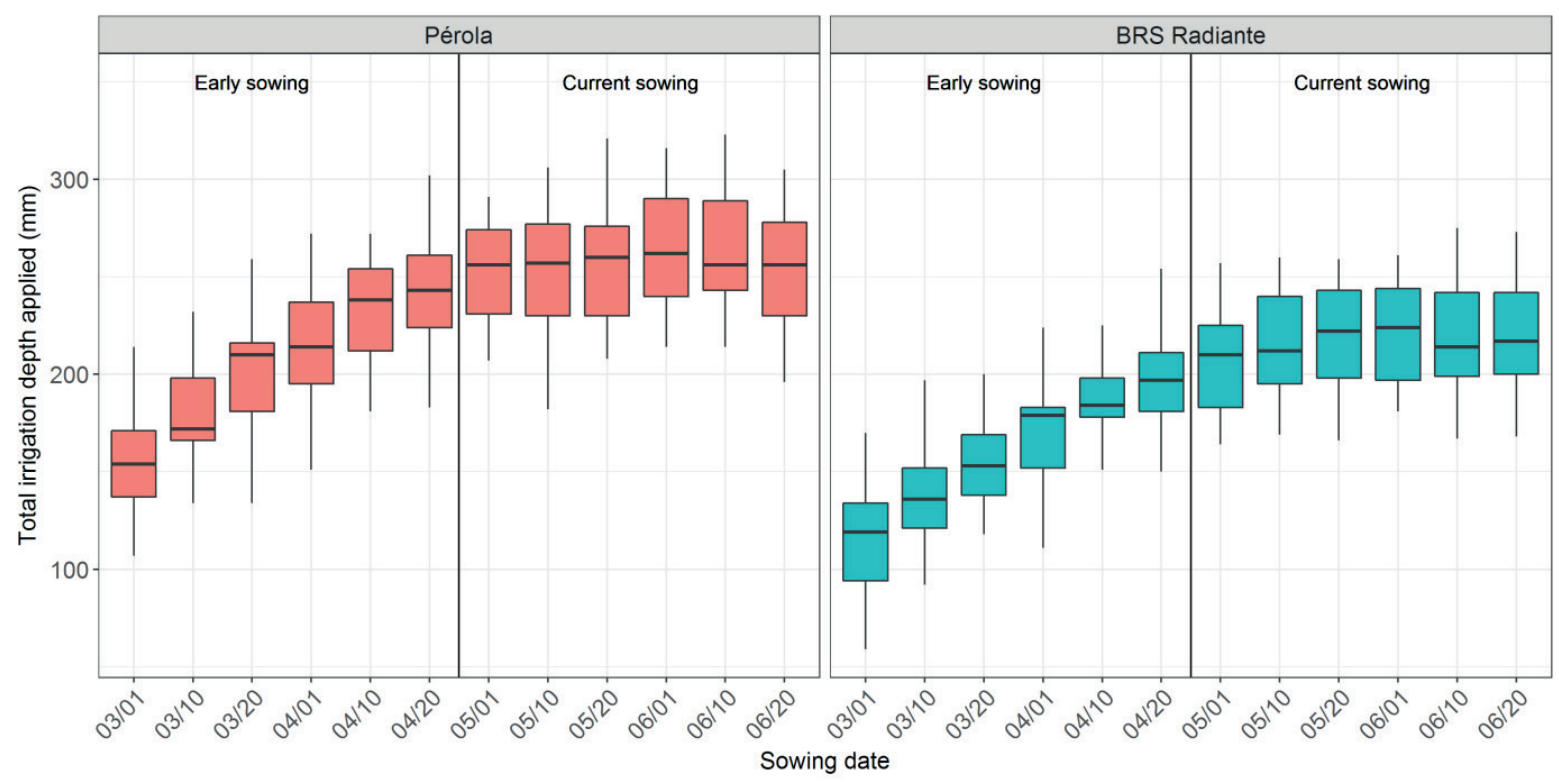

Figure 4. Total simulated irrigation depth for the Pérola and BRS Radiante common bean cultivars, for the sowing dates tested. In the box plot, boxes extend from the 25 th to the 75 th sample percentiles of yield, the thick horizontal line represents the median and whiskers extend to 1.5 times the interquartile range.
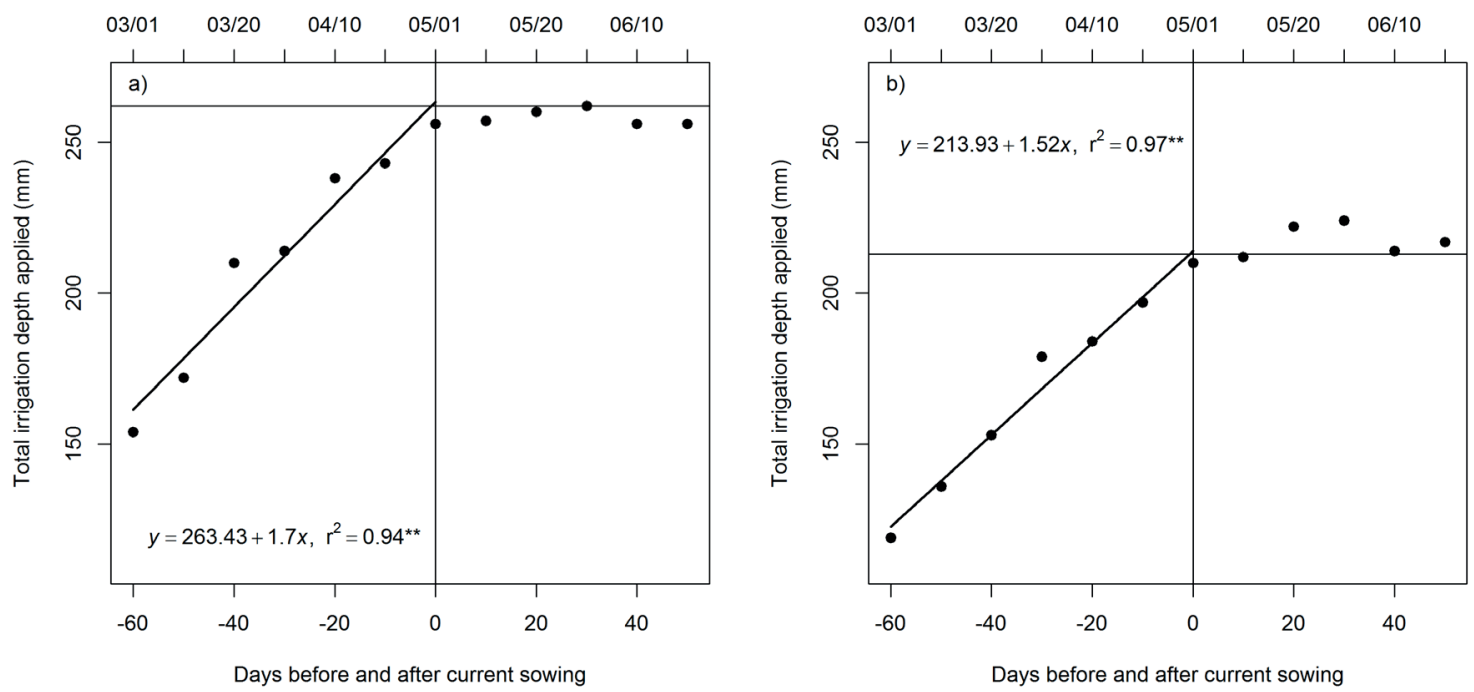

Figure 5. Water economy observed with advance sowing for the Pérola and BRS Radiante common bean cultivars. The inclined black line represents the linear regression. The full circles represent the simulated average irrigation depths needed per sowing date. ${ }^{* *}$ Regression coefficient significant at $1 \%$. 

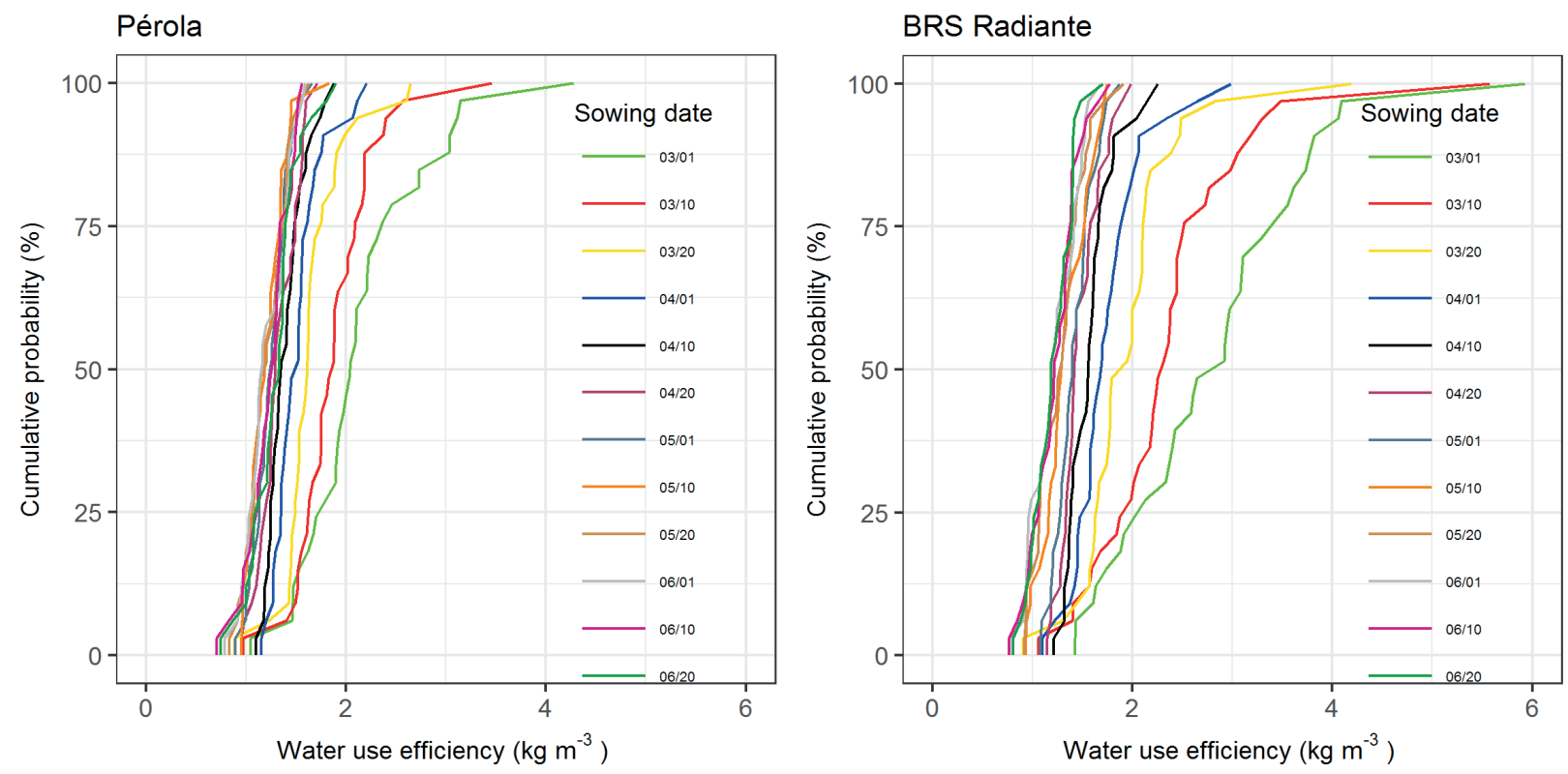

Figure 6. Cumulative probability of obtaining a simulated irrigation water use efficiency less than or equal to a specified value for the Pérola and BRS Radiante common bean cultivars, for the sowing dates tested.

The irrigation water use efficiency differed between the cultivars and the 12 simulated sowing dates, with average efficiency of $1.43 \mathrm{~kg} \mathrm{~m}^{-3}$ for Pérola and $1.62 \mathrm{~kg} \mathrm{~m}^{-3}$ for BRS Radiante, considering all the simulated sowing dates (Figure 6).

Sowings simulated in March showed the greatest probability of obtaining higher irrigation water use efficiency because of rainfall, and, for BRS Radiante, also the highest yields. This is the reason for its higher irrigation water use efficiency in that month $\left(2.39 \mathrm{~kg} \mathrm{~m}^{-3}\right)$, if compared to Pérola $\left(1.85 \mathrm{~kg} \mathrm{~m}^{-3}\right)$. From April 10, the irrigation water use efficiency observed in the other sowing dates varied $1.52-1.17 \mathrm{~kg} \mathrm{~m}^{-3}$ for Pérola and $1.69-1.19 \mathrm{~kg} \mathrm{~m}^{-3}$ for BRS Radiante.

Early sowing in March resulted in a considerably higher irrigation water use efficiency, with an increase in efficiency of $58 \%$ for Pérola and $101 \%$ for BRS Radiante, in relation to the minimum irrigation water use efficiency observed in the simulated sowing dates.

The irrigation water use efficiency at the sowing dates in which water supplementation was carried out exclusively by irrigation were close to those found in the literature for common bean. Bizari et al. (2009) and Cunha et al. (2013) obtained maximum irrigation water use efficiency of $1.05 \mathrm{~kg} \mathrm{~m}^{-3}$ and $0.92 \mathrm{~kg} \mathrm{~m}^{-3}$ for the Carioca Precoce and BRS Supremo cultivars, respectively.

\section{CONCLUSIONS}

1. The early sowing of common bean between March and April can improve the irrigation water use efficiency, if compared to the current sowing season;

2. Early sowing, in March, provides a higher common bean yield for the BRS Radiante cultivar. For Pérola, early sowing do not affect yield, if compared to late sowing in the fall/winter season;

3. Considering the common bean yield and water use efficiency, it is feasible to advance sowing to March for both cultivars.

\section{REFERENCES}

ANDRADE, M. J. B. de et al. Exigências edafoclimáticas. In: CARNEIRO, J. E.; PAULA JÚNIOR, T. J. de; BORÉM, A. (Eds.). Feijão: do plantio à colheita. Viçosa: Ed. UFV, 2015. p. 67-95.

ARF, O. et al. Manejo de solo, água e nitrogênio na cultura do feijão. Pesquisa Agropecuária Brasileira, v. 39, n. 2, p. 131-138, 2004.

BIZARI, D. R. et al. Consumo de água e produção de grãos do feijoeiro irrigado em sistemas plantio direto e convencional. Ciência Rural, v. 39, n. 7, p. 2073-2079, 2009.

BOUTRAA, T. Improvement of water use efficiency in irrigated agriculture: a review. Journal of Agronomy, v. 9, n. 1, p. 1-8, 2010. 
BRASIL, F. da C.; ZONTA, E.; OLIVEIRA, M. do R. G. Métodos de amostragem e quantificação para estudos do sistema radicular em condições de campo: uma revisão crítica. Revista de Ciências da Vida, v. 27, n. 2, p. 14-33, 2007.

BUSTAMANTE, M. M. C. et al. Impactos potenciais de mudanças climáticas sobre o funcionamento biogeoquímico dos ecossistemas do Cerrado. Brazilian Journal of Biology, v. 72, n. 3, p. 655-671, 2012.

CARDOSO, M. R. D.; MARCUZZO, F. F. N.; BARROS, J. R. Classificação climática de Köppen-Geiger para o Estado de Goiás e o Distrito Federal. Acta Geográfica, v. 8, n. 16, p. 40-55, 2014.

CUNHA, P. C. R. et al. Manejo da irrigação no feijoeiro cultivado em plantio direto. Revista Brasileira de Engenharia Agrícola e Ambiental, v. 17, n. 7, p. 735-742, 2013.

DALLACORT, R. et al. Soil water balance simulated by CROPGRO - Drybean model for edaphoclimatic conditions in Maringá. Revista Brasileira de Engenharia Agrícola e Ambiental, v. 14, n. 4, p. 351-357, 2010.

DE FRAITURE, C.; WICHELNS, D. Satisfying future water demands for agriculture. Agricultural Water Management, v. 97, n. 4, p. 502-511, 2010.

DIDONET, A. D. Importância do período de pré-floração na produtividade do feijoeiro. Pesquisa Agropecuária Tropical, v. 40, n. 4, p. 505-512, 2010.

DIDONET, A. D.; SILVA, S. C. da. Elementos climáticos e produtividade do feijoeiro. Informe Agropecuário, v. 25, n. 223, p. 13-19, 2004.

GOMES JUNIOR, F. G. et al. Rendimento do feijoeiro de inverno em resposta à época de semeadura e adubação nitrogenada em cobertura em diferentes estádios fenológicos. Acta Scientiarum Agronomy, v. 27, n. 1, p. 77-81, 2005.

HEINEMANN, A. B. et al. Center pivot irrigation management optimization of dry beans in humid areas. Transactions of the ASAE, v. 43, n. 6, p. 1507-1516, 2000.

HEINEMANN, A. B. et al. Drought impact on rainfed common bean production areas in Brazil. Agricultural and Forest Meteorology, v. 225, n. 1, p. 57-74, 2016.

HEINEMANN, A. B.; HOOGENBOOM, G.; FARIA, R. T. Determination of spatial water requirements at county and regional levels using crop models and GIS: an example for the State of Paraná, Brazil. Agricultural Water Management, v. 52, n. 3, p. 177-196, 2002.

INSTITUTO BRASILEIRO DE GEOGRAFIA E ESTATÍSTICA (IBGE). Levantamento sistemático da produção agrícola. Rio de Janeiro: IBGE, 2016.

INSTITUTO BRASILEIRO DE GEOGRAFIA E ESTATÍSTICA (IBGE). Produção agrícola municipal PAM. Rio de Janeiro: IBGE, 2012.
JONES, J. W. et al. The DSSAT cropping system model. European Journal of Agronomy, v. 18, n. 3-4, p. 235-265, 2003.

LIMA FILho, A. F.; COELhO FILHO, M. A.; HEINEMANN, A. B. Calibration and evaluation of CROPGRO model for cowpea in Recôncavo of Bahia - Brazil. Revista Brasileira de Engenharia Agrícola e Ambiental, v. 17, n. 12, p. 1286-1293, 2013 a.

LiMA FILho, A. F.; COElho FIlHo, M. A.; HEINEMANN, A. B. Determining the optimum sowing dates for cowpea based on CROPGRO model in Recôncavo of Bahia, Brazil. Revista Brasileira de Engenharia Agrícola e Ambiental, v. 17, n. 12, p. 12941300, 2013b.

LIMA, E. F. W. J. et al. Variação da área irrigada por pivô central no Cerrado entre 2002 e 2013. Irrigação \& Tecnologia Moderna, n. 104/105, p. 68-72, 2015.

MANTOVANI, C. M. et al. Estimativa de produtividade da cultura do feijão irrigado em Cristalina-GO, para diferentes lâminas de irrigação como função da uniformidade de aplicação. Engenharia Agrícola, v. 32, n. 1, p. 110-120, 2012.

MATZENAUER, R.; MALUF, J. R. T.; BUENO, A. C. Relações entre a evapotranspiração máxima do feijoeiro (Phaseolus vulgaris L.) com a evapotranspiração de referência e com a radiação solar global. Revista Brasileira de Agrometeorologia, v. 7, n. 2, p. 173-178, 1999.

OLIVEIRA, E. C. et al. The performance of the CROPGRO model for bean (Phaseolus vulgaris L.) yield simulation. Acta Scientiarum Agronomy, v. 34, n. 3, p. 239-246, 2012.

PINHEIRO, P. V. et al. Populational survey of arthropods on transgenic common bean expressing the rep gene from bean golden mosaic virus. GM Crops \& Food, v. 5, n. 3, p. 139-148, 2014.

RITCHIE, J. T. Model for predicting evaporation from a row crop with incomplete cover. Water Resources Research, v. 8, n. 5, p. 1204-1213, 1972.

SILVA, V. J. da et al. Desempenho de diferentes métodos de estimativa da evapotranspiração de referência diária em Uberlândia, MG. Bioscience Journal, v. 27, n. 1, p. 95-101, 2011.

TEIXEIRA, G. C. da S.; STONE, L. F.; HEINEMANN, A. B. Eficiência do uso da radiação solar e índices morfofisiológicos em cultivares de feijoeiro. Pesquisa Agropecuária Tropical, v. 45, n. 1, p. 9-17, 2015.

USA. Soil Conservation Service. Hydrology. Washington, DC: Soil Conservation Service, 1985.

VIEIRA, C.; ARAÚJO, G . A. de A.; CHAGAS, J. M. Efeitos das datas de plantio sobre o feijão cultivado no outono-inverno. Pesquisa Agropecuária Brasileira, v. 26, n. 6, p. 863-873, 1991. 